\title{
Kernos
}

Revue internationale et pluridisciplinaire de religion grecque antique

$30 \mid 2017$

Varia

\section{Dionysus Briseus}

\section{Kent Rigsby}

\section{OpenEdition \\ Journals}

\section{Electronic version}

URL: http://journals.openedition.org/kernos/2490

DOI: $10.4000 /$ kernos.2490

ISSN: 2034-7871

\section{Publisher}

Centre international d'étude de la religion grecque antique

\section{Printed version}

Date of publication: 1 October 2017

Number of pages: 85-89

ISSN: 0776-3824

\section{Electronic reference}

Kent Rigsby, « Dionysus Briseus », Kernos [Online], 30 | 2017, Online since 01 October 2019, connection on 18 September 2020. URL : http://journals.openedition.org/kernos/2490 ; DOI : https://doi.org/ $10.4000 /$ kernos. 2490

This text was automatically generated on 18 September 2020.

Kernos 


\title{
Dionysus Briseus
}

\author{
Kent Rigsby
}

1 In Roman Smyrna, the local branch of the theatrical guild, the Technitai of Dionysus, honored their god with a special epithet. ${ }^{1}$ In most cities the Actors' god was simply

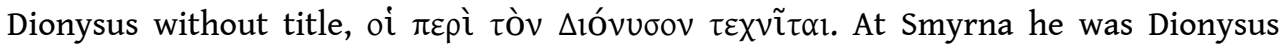

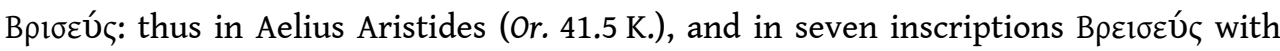
the grapheme for long iota that was common in Imperial times (e.g. I.Smyrna 600:

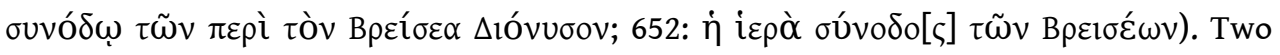

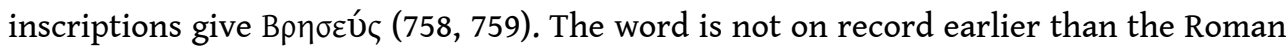
Empire. How to account for it?

2 The lexicographers assert two ways. The fullest version extant is in the Etymologicum Magnum (213 Gaisford):

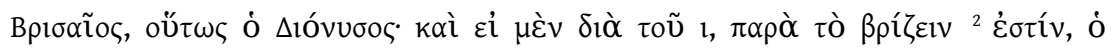

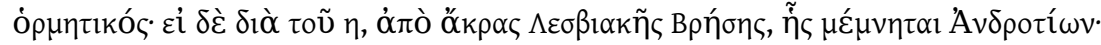

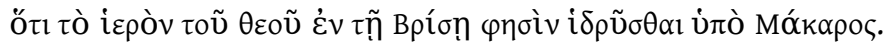

Brisaios, so Dionysus is called. And if with iota, it is from brilth〉ein ['to come forceully']: 'the impulsive one'. But if with eta, from the Lesbian cape Bresa, which Androtion mentions: for he says the sanctuary of the god at Brisa was founded by Macar. ${ }^{3}$

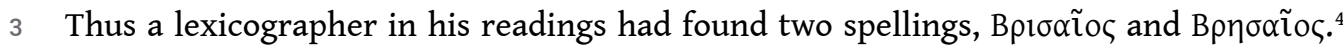
He distinguished them and offered two unconnected explanations. His explanations are for us a caution: the meaning of the epithet was unknown and the object of guesswork.

The first explanation has found no support among scholars. The second, by contrast, is grounded in reality. For we have reliable evidence for Lesbos' cult of Dionysus on cape

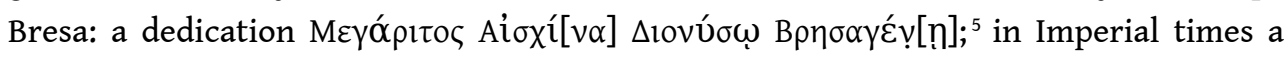

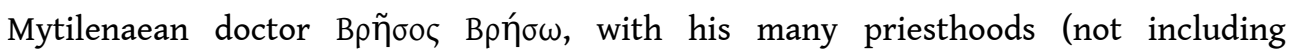
Dionysus). ${ }^{6}$ A distinguished man of Assos, four miles north of Lesbos, was the son of a

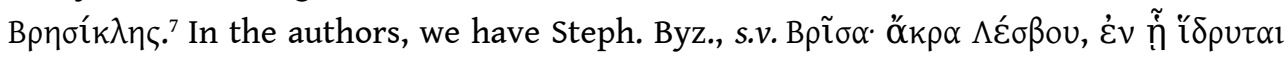

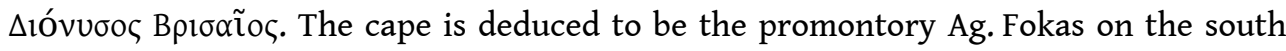

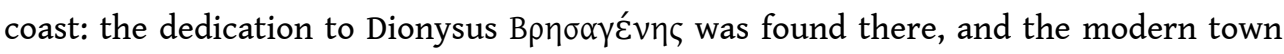
Vrisa is nearby. ${ }^{8}$ 
This Lesbian connection has long been approved. ${ }^{9}$ Most fully, M. Hasluck argued that the Smyrnaeans' cult of Dionysus was brought from Aeolian Lesbos either by some putative original founders of Smyrna, or else later. ${ }^{10}$ But we should wonder why a cult with a geographic epithet would have been carried over from Lesbos to Smyrna, to be attested only in Roman times. More important, nothing suggests that this was or had been a cult of the city of Smyrna, somehow inherited from Lesbos - on extant testimony, it belonged only to the Technitai, and at a late date. What special connection had they with a Lesbian cult or toponym in the form of its offshoot in Smyrna?

Wilamowitz, ${ }^{11}$ by contrast, urged that the Cean nymphs called Brisai ${ }^{12}$ disproved the Lesbian source of the epithet at Smyrna: rather this was a wide-spread name, in origin Boeotian, ${ }^{13}$ and leading finally to Homeric Briseis, 'the girl from Brisa' on Lesbos. He proposed no meaning for the word or reason for its use at Smyrna.

7 The spelling variants are admittedly dubious evidence, with $1 / \varepsilon l / \eta$ sounding the same;

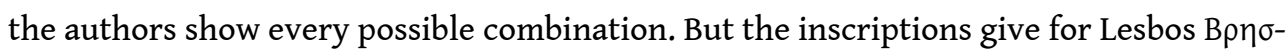

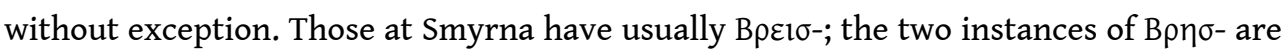
known only from early copies (I.Smyrna 758 and 759, the stones lost; Petzl reproduces the drawings, in which eta is clear - but EI and $\mathrm{H}$ are easily confused). I suggest that Lesbian B $\rho \eta \sigma-$ and Smyrnaean $B \rho(\varepsilon)_{1 \sigma-}$ are distinct and not connected. We can suspect instead that the Artists of Roman Smyrna selected for their god an epithet that was literary and recherché, rather than a civic cult title of foreign origin.

8 Two authors offer material independent of the lexicographers. Aelius Aristeides, a man of Smyrna, describes types of Dionysus: "as with men, he is both beardless and Briseus",

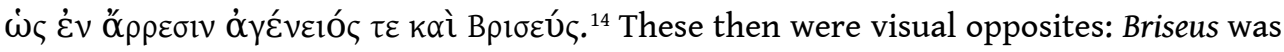
a bearded Dionysus. In turn, Macrobius cites two epithets for a bearded Dionysus: "with bearded appearance, and as an old man, as Greeks call him sometimes Bassareus,

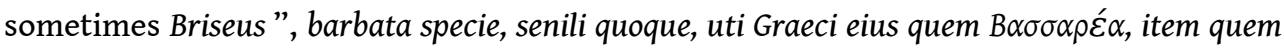

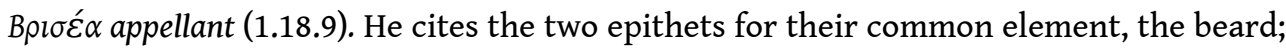
but Bassareus also signals a region, Thrace.

9 Bassareus identifies Dionysus as leader of the raving Thracian bacchantes, for the

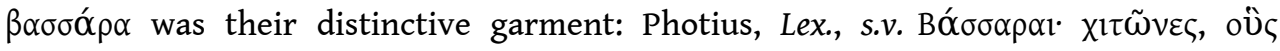

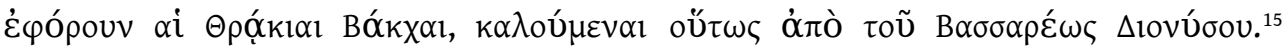
Horace invokes the leader of the Sithonian/Thracian Bacchai as candide Bassareu. ${ }^{16}$ Thrace was the scene of the dismemberment of Orpheus; the authors make clear the raging character of the Thracian maenads, and from an early date. Anacreon, with enough wine, will turn violent and raving: "I will again be a bassareus", $\dot{\omega} \varsigma \grave{\alpha} v$

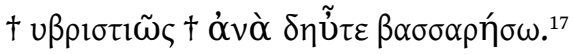

10 Thus Bassareus points to the Thracian version of Dionysus, and this suggests an approach to Briseus. Just as Horace's Sithones were one Thracian tribe, another was the Brisei. These are the Briseorum latronum in a career inscription of the first century ( $A E$ 1956, 124.16) and the Brisas in Pliny. ${ }^{18}$ This, I would urge, is the origin of the Artists' name for their god: it was a learned way of specifying the Thracian Dionysus, leader of the ecstatic maenad chorus. Briseus was a synecdoche for 'Thracian', like Horace's Sithonii - a bookish affectation. We may even guess that the Actors derived the epithet Briseus from a tragedy now lost to us.

11 If the theatrical guild in Smyrna portrayed their god under this version of his myths, and could even call themselves Briseis (I.Smyrna 652), that will help explain another 
usage that is unique to the Artists of Smyrna: they liked to describe themselves as

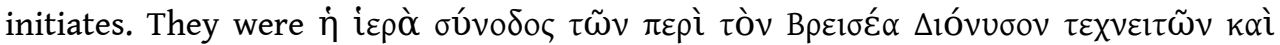

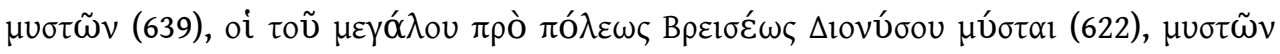

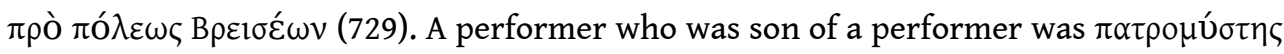
$(731,732) .{ }^{19}$ Theater professionals elsewhere made no such claim. This too was an affectation, and consistent with honoring the Thracian Dionysus: the Actors were his

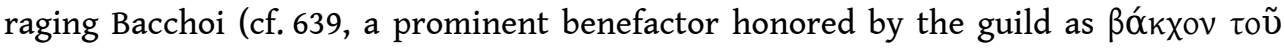
$\theta \varepsilon \circ \tilde{)}$.

By Roman times it was normal that maenads included men as well as women. ${ }^{20}$ The Technitai of Smyrna would be distinctive in being male only - but (again) there is in their pose as mystai a large admixture of metaphor. In antiquity as now, 'initiation' could be used describe a wide range of inductions and introductions. ${ }^{21}$ The Technitai had every right to call themselves a thiasos and a choros, terms rich in their implication of special membership. But though we might call this guild's language of initiation an affectation (not 'real' mysteries, if that is meaningful), ${ }^{22}$ we need not deny the possibility that induction to the theatrical guild involved both ritual and the revelation of some insider knowledge. The metaphor of initiation would be appropriate.

\section{BIBLIOGRAPHY}

N. BELAYCHE, "L'évolution des formes rituelles", in L. BRICAULT, C. BONNET (eds.), Panthée: Religious Transformations in the Graeco-Roman Empire, Leiden/Boston, 2013, p. 17-40.

Ph. BorgeAud, "Les mystères", in L. BRICAUlt, C. BONNET (eds.), Panthée: Religious Transformations in the Graeco-Roman Empire, Leiden/Boston, 2013, p. 131-144.

BOUTAN, “Topographie de l'île de Lesbos”, Archives des missions scientifiques Ser. I 5 (1856), p. 273364 .

BÜRCHNER, “Brisa”, RE III (1897), col. 855.

C. FARAONE, "Gender Differentiation and Role Models in the Worship of Dionysos: The Thracian and Thessalian Pattern", in A. BERNABÉ et al. (eds.), Redefining Dionysos, Berlin/Boston, 2013, p. 120143.

M. HASLUCK, "Dionysus at Smyrna”, ABSA 19 (1912/3), p. 89-94.

A. HENRICHS, "Male Intruders among the Maenads", in H.D. EVJEN (ed.), Mnemai: Classical Studies in Memory of Karl. K. Hulley, Chico, 1984, p. 69-91.

C. ISLER-KERÉNYI, “Dionysos: dio delle donne? Iconografia dionisiaca II”, in F. BERTI (ed.), Dionysos. Mito e mistero, Ferrara, 1991, p. 293-307.

A.-F. JACCoTtET, Choisir Dionysos I, Zürich, 2003.

A.-F. JACCOTTET, "Les mystères dionysiaques pour penser les mystères antiques ?", Mètis N.S. 14

(2016), p. 75-94. 
O. KERN, “Dionysos”, RE V (1903), col. 1027.

R. KOLDEWEY, Die antiken Baureste der Insel Lesbos, Berlin, 1890.

C.T. NEWTON, Travels and Discoveries in the Levant II, London, 1865.

M.P. NILSSON, The Dionysiac Mysteries in the Hellenistic and Roman Age, Lund, 1957.

A. D. Nock, "Hellenistic Mysteries and Christian Sacraments", Mnemosyne Ser. IV 5 (1952), p. $177-$ 213 [republished in NOCK (1972), p. 791-820].

A.D. NOCK, Essays on Religion and the Ancient World I-II, Cambridge [Mass.], 1972.

H.-G. PFLAUM, Les carrières procuratoriennes I, Paris, 1960.

V. PIRENNE-DELFORGE, P. SCARPI, "Les cultes à mystères. Introduction”, in C. BONNET et al. (eds.),

Religions orientales - culti misterici, Stuttgart, 2006, p. 159-162.

E. POTTIER, A. HAUVETtE-BESNAUlt, “Inscriptions de Lesbos”, BCH 4 (1880), p. 417-448.

C. RIEDWEG, Mysterienterminologie bei Platon, Philon und Klemens von Alexandrien, Berlin/New York, 1987.

M. TOD, “Notes on Some Inscriptions from Asia Minor", CR 29 (1915), p. 1-4.

U. WILAMOWITZ, Homerische Untersuchungen, Berlin, 1884 (Phil. Unters., 7).

\section{NOTES}

1. PETZL, on I.Smyrna 729, lists the testimonia.

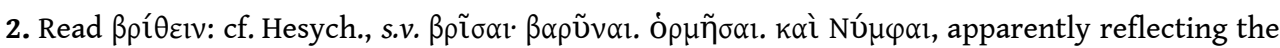
same source.

3. Jacoby (on Androtion, FGrHist $324 \mathrm{~F} 56$ ) commented that this last element may not come from Androtion (emending e.g. porìv).

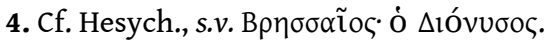

5. IG XII.2 478, late Hellenistic or Roman.

6. IG XII.2 484 [SAMAMA, Les médecins, no. 119].

7. I.Assos 8, late Hellenistic.

8. BOUTAN (1856), p. 303-306; confirmed when the dedication was discovered, POTTIER - HAUVETTEBESNAULT (1880), p. 445. Cf. NEWTON (1865), p. 13; KOLDEWEY (1890), p. 63-64; BÜRCHNER (1897), col. 855 (who however denies the relevance of modern Vrisa).

9. Already in 1828 DINDORF on Aristides Or. 4 (= 41.5 K.); POTTIER - HAUVETTE-BESNAULT (1880), p. 446 (publishing the dedication); KERN (1903), col. 1027.

10. HASLUCK (1912/3) p. 89-94.

11. WILAMOWITZ (1884) p. 409-412.

12. Heraclides Lembus, Excerpt. Polit., 27.

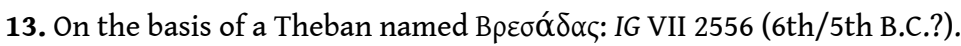

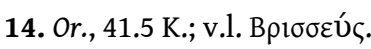

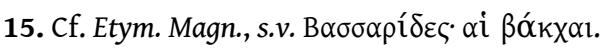

16. Carm. 1.18.9-11; on the synecdoche in monet Sithoniis non levis Eubius, Porphyry explained: Sithonii Thraces sunt, qui per uinulentiam inuitati etiam inlicitos concubitus audent (p. 27 HOLDER).

17. PMG 356, from Ath. 427a: “† violently † turn into a drunken madman", oLSON in the Loeb

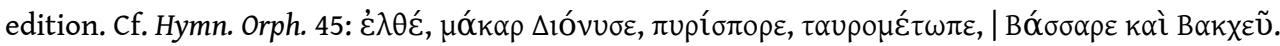

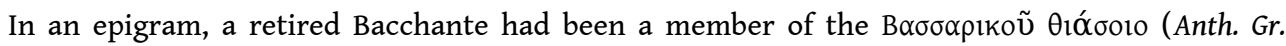




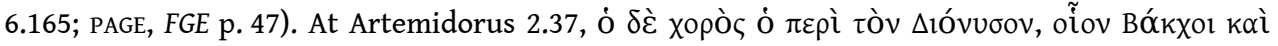

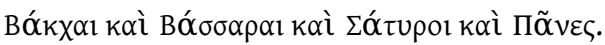

18. HN 4.18 (v.l. Brysas). On the text see PFLAUM (1960), p. 489.

19. So TOD (1915), p. 1.

20. HENRICHS (1984), p. 70. On gender roles in Dionysiac cult, see JACCOTTET (2003), p. 64-100; FARAONE (2013), p. 120-143; and in Dionysiac imagery, ISLER-KERÉNYI (1991), p. 293-307.

21. Cf. e.g. to philosophy: see NocK (1952), p. 185-190 [repr. NocK (1972), p. 797-802].

22. They "seem to have been an association of actors which posed as a mystery association", NILSSON (1957) p. 47-48, cited by PETZL on I.Smyrna 639. For the range and metaphorical use of “mystai/mysteries”, see RIEDWEG (1987); PIRENNE-DELFORGE - SCARPI (2006), p. 159-162; BELAYCHE (2013), p. 39; BORGEAUD (2013), p. 137-144; JACCOTTET (2016), p. 88-90.

\section{ABSTRACTS}

The theatrical guild in Roman Smyrna assigned the epithet Briseus to Dionysus: the reference was probably to the Brisei of Thrace, and honoring Thracian Dionysus, leader of the Bacchai, is consistent with the Smyrnaean actors styling themselves mystai.

Les technites de la Smyrne romaine qualifiaient Dionysos de Briseus: l'épiclèse faisait probablement référence aux Brisei de Thrace, et l'hommage rendu au Dionysos thrace, patron des bacchants, entre en résonance avec le fait que les acteurs de Smyrne se mettaient en scène eux-mêmes comme des mystes.

\section{AUTHOR}

\section{KENT RIGSBY}

Duke University

krigsby@duke.edu 